\title{
Application of $\mathrm{Al} / \mathrm{B} / \mathrm{Fe}_{2} \mathrm{O}_{3}$ Nano Thermite in Composite Solid Propellant
}

\author{
Jingke Deng, Guoping Li*, Lianhua Shen, Yunjun Luo* \\ School of Materials Science and Engineering, Beijing Institute of Technology, Beijing, PR China
}

Received: $5^{\text {th }}$ November 2015; Revised: $4^{\text {th }}$ December 2015; Accepted: $3^{\text {th }}$ December 2015

\begin{abstract}
Hydroxyl-terminated polybutadiene (HTPB) propellant were prepared with different content of $\mathrm{Al} / \mathrm{B} / \mathrm{Fe}_{2} \mathrm{O}_{3}$ nano thermite, and the mechanical, thermal and energetic performances were studied. $\mathrm{Al} / \mathrm{B} / \mathrm{Fe}_{2} \mathrm{O}_{3}$ nano thermite exhibited good compatibility with HTPB and dioctyl sebacate (DOS) through differential scanning calorimetry (DSC) tests. Mechanical experiments show that the mechanical properties of HTPB propellant could be improved by the addition of a small quantity of $\mathrm{Al} / \mathrm{B} / \mathrm{Fe}_{2} \mathrm{O}_{3}$ nano thermite, compared with the absence of $\mathrm{Al} / \mathrm{B} / \mathrm{Fe}_{2} \mathrm{O}_{3}$ nano thermite. For example, with the addition of $3 \% \mathrm{Al} / \mathrm{B} / \mathrm{Fe}_{2} \mathrm{O}_{3}$ nano thermite, the tensile strength and elongation of propellant had the increase of $15.3 \%$ and $32.1 \%$, respectively. Thermal analysis indicated that the decomposition of ammonium perchlorate (AP) in HTPB propellant could be catalyzed by $\mathrm{Al} / \mathrm{B} / \mathrm{Fe}_{2} \mathrm{O}_{3}$ nano thermite, the hightemperature exothermic peak of AP was shifted to lower temperature by $70.8{ }^{\circ} \mathrm{C}$ when the content of $\mathrm{Al} / \mathrm{B} / \mathrm{Fe}_{2} \mathrm{O}_{3}$ nano thermite was $5 \%$, and the heat released was enhanced by $70 \%$. At the same time, the heat of explosion of HTPB propellant could also be enhanced by the addition of $\mathrm{Al} / \mathrm{B} / \mathrm{Fe}_{2} \mathrm{O}_{3}$ nano thermite. Copyright (C) 2016 BCREC GROUP. All rights reserved
\end{abstract}

Keywords: $\mathrm{Al} / \mathrm{B} / \mathrm{Fe}_{2} \mathrm{O}_{3}$ nano thermite; HTPB propellant; mechanical performance; thermal analysis; heat of explosion

How to Cite: Deng, J., Li, G., Shen, L., Luo, Y. (2016). Application of $\mathrm{Al} / \mathrm{B} / \mathrm{Fe}_{2} \mathrm{O}_{3}$ Nano Thermite in Composite Solid Propellant. Bulletin of Chemical Reaction Engineering \& Catalysis, 11 (1): 109-114. (doi:10.9767/bcrec.11.1.432.109-114)

Permalink/DOI: http://dx.doi.org/10.9767/bcrec.11.1.432.109-114

\section{Introduction}

Nano thermites are a class of energetic materials that are composed of nano-sized metal fuel and oxidizer particles. During the past years, the most widely reported thermites are: $\mathrm{Al} / \mathrm{Fe}_{2} \mathrm{O}_{3}, \mathrm{Al} / \mathrm{CuO}, \mathrm{Al} / \mathrm{KMnO}_{4}, \mathrm{Al} / \mathrm{WO}_{3}, \mathrm{Al} / \mathrm{MoO}_{3}$, etc. [1-5]. As the nanoscale in particle size reduces the mass transport distance between the fuel and oxidizer, and the high ratio of surface area to volume of the nanoparticles leads to

* Corresponding Author.

E-mail: yjluo@bit.edu.cn (Y. Luo) and girlping3114@bit.edu.cn (G. Li) more intimate fuel/oxidant contact, the rate of energy release of nano thermites is primarily controlled by chemical kinetics rather than mass transport. Therefore, the energy release of these materials is improved greatly, and the reaction rate becomes faster than that of the conventional energetic materials, simultaneously. For example, the energy density of $\mathrm{Al} / \mathrm{Fe}_{2} \mathrm{O}_{3}$ is $16.5 \mathrm{~kJ} / \mathrm{cm}^{3}$, which is two times higher than that of trinitrotoluene (TNT) with $7.5 \mathrm{~kJ} / \mathrm{cm}^{3}[6]$.

In composite solid propellant, reactive metal powders such as $\mathrm{Al}, \mathrm{B}$ and $\mathrm{Mg}$ are often used to enhance the specific impulse, density and to improve the combustion property [7]. As the su- 
perior energetic performance, nano thermites can be added in propellant to replace some of the metal powder to improve the performance of solid propellant. Moreover, ammonium perchlorate (AP) is a widely used oxidizing agent in solid rocket propellant, and the thermal decomposition process of AP can be catalyzed by nanocrystalline transition metal oxides such $\mathrm{Fe}_{2} \mathrm{O}_{3}$, which is also a common used oxidizer in nano thermites [8]. Hence, the addition of $\mathrm{Fe}_{2} \mathrm{O}_{3}$ based nano thermites can improve the combustion performance of propellant at the same time.

In our previous work, the $\mathrm{Al} / \mathrm{B} / \mathrm{Fe}_{2} \mathrm{O}_{3}$ nano thermites were prepared by a sol-gel synthetic approach combined with an ultrasonic method [9]. The test results showed that the samples were uniformly compounded and indeed energetic, furthermore, the materials were also relatively insensitive to standard impact. Therefore, it can be expected to replace a part of $\mathrm{Al}$ by $\mathrm{Al} / \mathrm{B} / \mathrm{Fe}_{2} \mathrm{O}_{3}$ nano thermites to improve the performance of Hydroxyl-terminated polybutadiene (HTPB) propellant. To be applied in propellant, the chemical compatibility between $\mathrm{Al} / \mathrm{B} / \mathrm{Fe}_{2} \mathrm{O}_{3}$ nano thermite and binder system was first studied to ensure safety, and then the mechanical, thermal and energetic performances of propellant with different content of $\mathrm{Al} / \mathrm{B} / \mathrm{Fe}_{2} \mathrm{O}_{3}$ nano thermite were also studied.

\section{Materials and Methods}

\subsection{Materials}

HTPB (OH value $0.72 \mathrm{mmol} / \mathrm{g})$ with a molecular weight of 2800 , AP with an average di- ameter of $250 \mu \mathrm{m}$ and $100 \mu \mathrm{m}$ were supplied by Liming Research Institute of Chemical Industry, Henan, China dioctyl sebacate (DOS) and isophorone diisocyanate (IPDI, NCO index: $8.99 \mathrm{mmol} / \mathrm{g}$ ) were obtained from Bayer. $\mathrm{Al} / \mathrm{B} / \mathrm{Fe}_{2} \mathrm{O}_{3}$ nano thermites were prepared by ourselves [9]. The $\mathrm{Al}$ fuel has an $80 \mathrm{~nm}$ average diameter and the $\mathrm{B}$ fuel has a $15 \mu \mathrm{m}$ average diameter. Both were supplied by Nano Material Engineering Company (Jiaozuo, China).

\subsection{Preparation of $\mathrm{Al} / \mathrm{B} / \mathrm{Fe}_{2} \mathrm{O}_{3}$ nano ther- mite}

A detailed propellant composition is provided in Table 1 . For preparation of propellants, first $\mathrm{Al} / \mathrm{B} / \mathrm{Fe}_{2} \mathrm{O}_{3}$ nano thermite were dispersed in a mixture consisting of HTPB and dioctyl sebacate (DOS) for $20 \mathrm{~min}$ at $60{ }^{\circ} \mathrm{C}$ for wetting. Then Al, AP and curing agent isophorone diisocyanate (IPDI) were subsequently added and mixed thoroughly, followed by degassing in a vacuum oven at $30{ }^{\circ} \mathrm{C}$. The propellant slurry was finally being poured into a mold, and cured in $60{ }^{\circ} \mathrm{C}$ for 7 days.

\subsection{Characterization methods}

Chemical compatibility was studied by differential scanning calorimetry (DSC), the difference values of the decomposition peak temperature $\left(\Delta \mathrm{T}_{\mathrm{p}}\right)$ between mixed materials were used to determine the chemical compatibility of two materials [10]. The mass ratio of $\mathrm{Al} / \mathrm{B} / \mathrm{Fe}_{2} \mathrm{O}_{3}$ nano thermite and HTPB or DOS was $1: 1$. Table 2 shows the evaluated standard

Table 1. Composition and serial numbers of propellants

\begin{tabular}{ccccccc}
\hline \multirow{2}{*}{ Serial number } & \multicolumn{7}{c}{ Composition (wt. \%) } \\
\cline { 2 - 7 } & HTPB & IPDI & DOS & $\mathrm{Al}$ & $\mathrm{AP}$ & $\mathrm{Al} / \mathrm{B} / \mathrm{Fe}_{2} \mathrm{O}_{3}$ \\
\hline 1 & 9.26 & 0.74 & 5 & 18 & 67 & 0 \\
2 & 9.26 & 0.74 & 5 & 17 & 67 & 1 \\
3 & 9.26 & 0.74 & 5 & 15 & 67 & 3 \\
4 & 9.26 & 0.74 & 5 & 13 & 67 & 5 \\
\hline
\end{tabular}

Table 2. Evaluated standard of compatibility for explosive and contacted materials

\begin{tabular}{ccc}
\hline Criterial $\Delta \mathrm{T}_{\mathrm{p}}{ }^{\circ} \mathrm{C}$ & Rating & Note \\
\hline$\leq 2$ & $\mathrm{~A}$ & compatible or good compatibility \\
$3 \sim 5$ & $\mathrm{~B}$ & slightly sensitized or fair compatibility \\
$6 \sim 15$ & $\mathrm{C}$ & sensitized or poor compatibility \\
$\geq 15$ & $\mathrm{D}$ & hazardous or bad compatibility \\
\hline
\end{tabular}


of compatibility for explosive and contacted materials.

The mechanical test of dumb-bell specimens were measured with a tensile testing machine (Instron-6022, Shimadzu Co., Ltd.) at a crosshead speed of $100 \mathrm{~mm} / \mathrm{min}$ at room temperature. Five specimens were tested for each sample to obtain average values. Thermal performance was tested by and differential scanning calorimetry (DSC) (METTLERTOLED, United States), from room temperature to $1000{ }^{\circ} \mathrm{C}$ at a heating rate of $10{ }^{\circ} \mathrm{C} / \mathrm{min}$ under $\mathrm{N}_{2}$ atmosphere. The heats of explosive of the propellant samples were evaluated in a $\mathrm{N}_{2}$ atmosphere using the Parr 6200 Calorimeter (Parr Instrument Company, United States).

\section{Results and Discussion}

\subsection{Compatibility between $\mathrm{Al} / \mathrm{B} / \mathrm{Fe}_{2} \mathrm{O}_{3}$ nano thermite and HTPB and DOS}

DSC method is a widely used method to estimate the compatibility between energetic materials [11]. The DSC curves of HTPB, DOS and their mixtures with $\mathrm{Al} / \mathrm{B} / \mathrm{Fe}_{2} \mathrm{O}_{3}$ nano thermite were shown in Figure 1. From the decomposition peak observed on the curves, $\Delta \mathrm{T}_{\mathrm{p}}$ can be calculated, $\Delta \mathrm{T}_{\mathrm{p}}=\mathrm{T}_{\mathrm{p} 1}-\mathrm{T}_{\mathrm{p} 2}$, where $\mathrm{T}_{\mathrm{p} 1}$ is the maximum exothermic peak temperature of single system; $\mathrm{T}_{\mathrm{p} 2}$ is the maximum exothermic peak temperature of mixture system.

The results were shown in Figure 3. It can be seen in Figure 3 that the $\Delta \mathrm{T}_{\mathrm{p}}$ between HTPB and corresponding mixture is $0.2{ }^{\circ} \mathrm{C}$ while it is $1.5^{\circ} \mathrm{C}$ between DOS and corresponding mixture. According to tab.2, the results indicate that the compatibility ratings are both $\mathrm{A}$ for the two mixtures [11], $\mathrm{Al} / \mathrm{B} / \mathrm{Fe}_{2} \mathrm{O}_{3}$ nano thermite has good compatibility with both HTPB and DOS, and it can be used in HTPB propellant.

\subsection{Effects of $\mathrm{Al} / \mathrm{B} / \mathrm{Fe}_{2} \mathrm{O}_{3}$ nano thermite on the mechanical properties of HTPB pro- pellant}

Figure 2 shows the mechanical properties of propellant prepared with different contents of $\mathrm{Al} / \mathrm{B} / \mathrm{Fe}_{2} \mathrm{O}_{3}$ nano thermite. With the increasing content of $\mathrm{Al} / \mathrm{B} / \mathrm{Fe}_{2} \mathrm{O}_{3}$ nano thermite, both tensile strength and elongation of propellant raise at first and reduce later. Compared with the propellant with no $\mathrm{Al} / \mathrm{B} / \mathrm{Fe}_{2} \mathrm{O}_{3}$ nano thermite (sample 1), the tensile strength and elongation of propellant prepared with $3 \% \mathrm{Al} / \mathrm{B} / \mathrm{Fe}_{2} \mathrm{O}_{3}$ nano thermite (sample 3) have the increase of $15.3 \%$ and $32.1 \%$ respectively. As is prepared by sol-gel method, few hydroxyl groups will exist on the surface of $\mathrm{Al} / \mathrm{B} / \mathrm{Fe}_{2} \mathrm{O}_{3}$ nano thermite though it has been heat-treated to $350{ }^{\circ} \mathrm{C}$ before use [12]. The hydroxyl groups react with the curing agent IPDI during the curing process, and the extra crosslink points will be formed on the surface of $\mathrm{Al} / \mathrm{B} / \mathrm{Fe}_{2} \mathrm{O}_{3}$ nano thermite, accordingly the mechanical properties are enhanced. As the content of $\mathrm{Al} / \mathrm{B} / \mathrm{Fe}_{2} \mathrm{O}_{3}$ nano thermite continue to increase, more surface hydroxyl groups participate in the curing reaction, which leads to an incomplete network in propellant, and the mechanical properties reduce correspondingly.
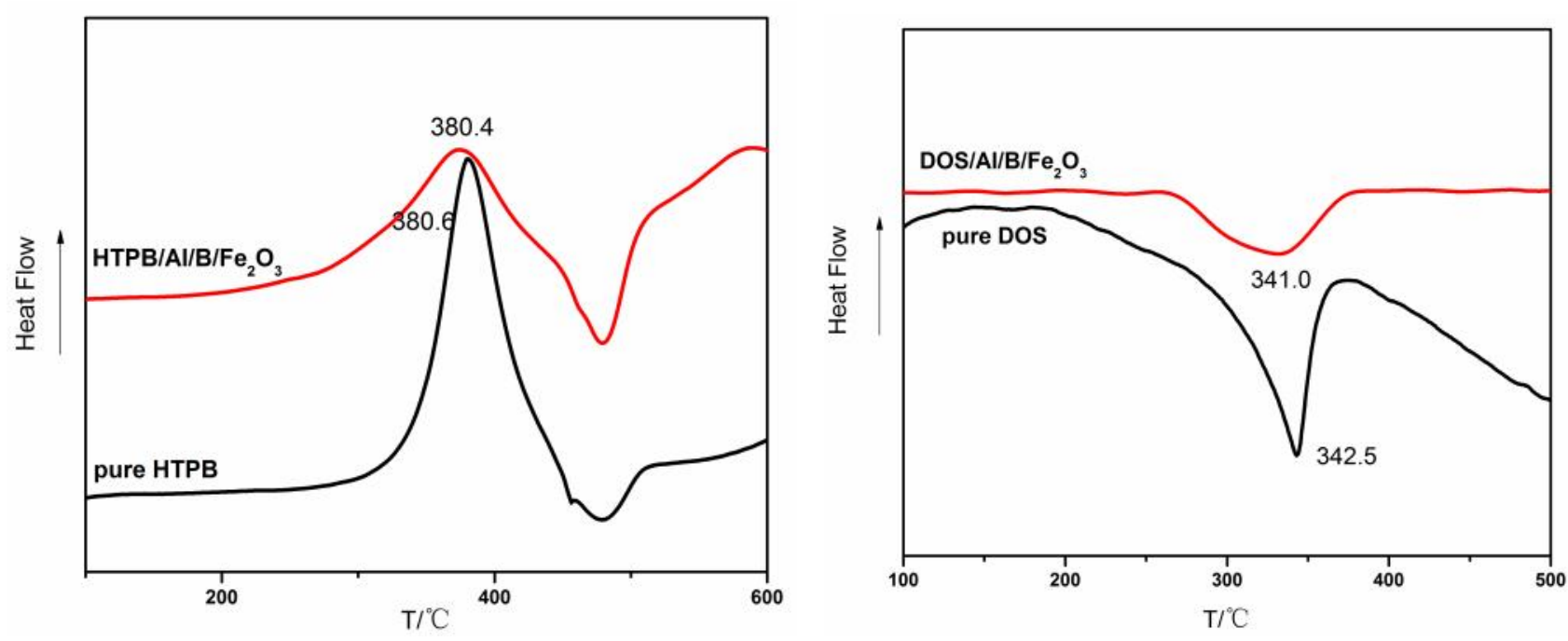

Figure 1. DSC curves of HTPB, DOS and their mixtures with $\mathrm{Al} / \mathrm{B} / \mathrm{Fe}_{2} \mathrm{O}_{3}$ nano thermite 
3.3. Effects of $\mathrm{Al} / \mathrm{B} / \mathrm{Fe}_{2} \mathrm{O}_{3}$ nano thermite on the thermal properties of HTPB propellant

The DSC curves of HTPB propellant samples prepared with different contents of $\mathrm{Al} / \mathrm{B} / \mathrm{Fe}_{2} \mathrm{O}_{3}$ nano thermite are presented in Figure 3. Three exothermic peaks can be seen on the DSC curve of sample 1 at the temperature of $319.1,375.3$ and $423.4^{\circ} \mathrm{C}$, and correspond to the decomposition of HTPB, low-temperature decomposition of AP and high-temperature decomposition of $\mathrm{AP}$, respectively.

As the nano structure and the existence of $\mathrm{Fe}_{2} \mathrm{O}_{3}, \mathrm{Al} / \mathrm{B} / \mathrm{Fe}_{2} \mathrm{O}_{3}$ has a positive effect on the decomposition of AP primarily [13]. The DSC

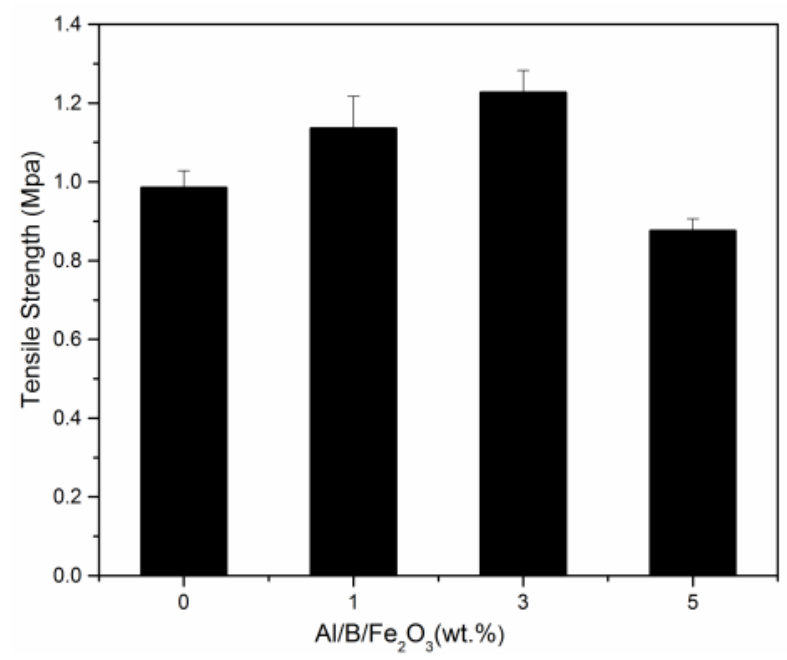

curves of sample 2, 3 and 4 show a noticeable difference in the decomposition patterns of AP. In the DSC curves, the high-temperature exothermic peaks of AP in sample 2, 3 and 4 are shifted to lower temperature compares with sample 1 , which indicates $\mathrm{Al} / \mathrm{B} / \mathrm{Fe}_{2} \mathrm{O}_{3}$ nano thermite exhibits catalytic activity on the thermal decomposition of AP effectively, and has little effect on the decomposition of HTPB. Meanwhile, as the increasing content of $\mathrm{Al} / \mathrm{B} / \mathrm{Fe}_{2} \mathrm{O}_{3}$, the exothermic peaks of AP become sharp and higher, which indicates a faster decomposition rate and higher heat release [14].

Table 4 shows the thermal parameters of four samples. Compares with the propellant pre-

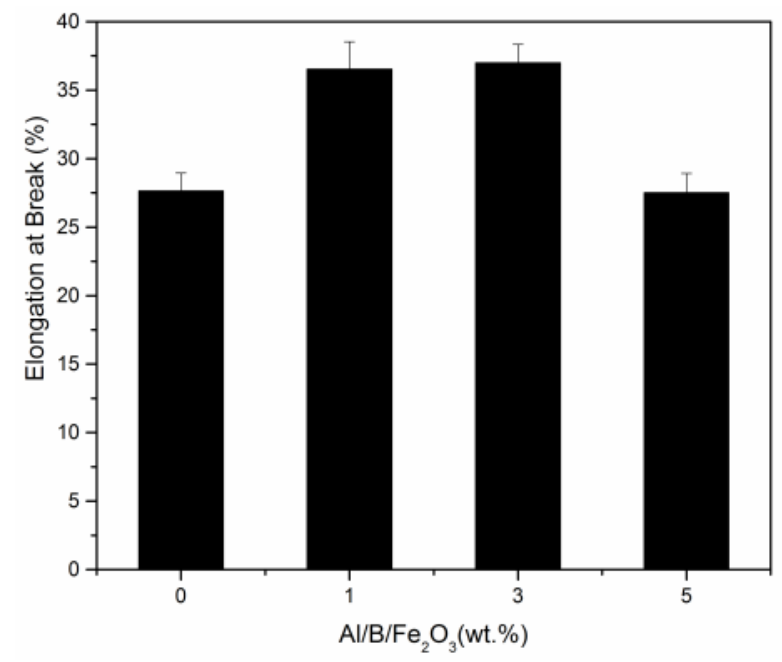

Figure 2. Mechanical properties of propellant prepared with different contents of $\mathrm{Al} / \mathrm{B} / \mathrm{Fe}_{2} \mathrm{O}_{3}$ nano thermite

Table 3. $\Delta \mathrm{T}_{\mathrm{p}}$ calculated from the DSC curves and the evaluation results

\begin{tabular}{|c|c|c|c|c|c|}
\hline \multicolumn{2}{|c|}{ System } & \multicolumn{3}{|c|}{ Peak temperature } & \multirow{2}{*}{$\begin{array}{c}\text { Rating } \\
\text { - }\end{array}$} \\
\hline Mixture System (1:1) & Single system & $\mathrm{T}_{\mathrm{p} 1} /{ }^{\circ} \mathrm{C}$ & $\mathrm{T}_{\mathrm{p} 2} /{ }^{\circ} \mathrm{C}$ & $\Delta \mathrm{T}_{\mathrm{p}} /{ }^{\circ} \mathrm{C}$ & \\
\hline $\mathrm{Al} / \mathrm{B} / \mathrm{Fe}_{2} \mathrm{O}_{3}-\mathrm{HTPB}$ & НТРB & 380.4 & 380.6 & 0.2 & A \\
\hline $\mathrm{Al} / \mathrm{B} / \mathrm{Fe}_{2} \mathrm{O}_{3}-\mathrm{DOS}$ & DOS & 341.0 & 342.5 & 1.5 & $\mathrm{~A}$ \\
\hline
\end{tabular}

Table 4. Thermal parameters of four samples

Serial number Content of $\mathrm{Al} / / \mathrm{B} / \mathrm{Fe}_{2} \mathrm{O}_{3} / \%$
High-temperature exothermic peaks of $\mathrm{AP} /{ }^{\circ} \mathrm{C}$
Heat release $(\Delta \mathrm{H})$ $(\mathrm{J} / \mathrm{g})$

\begin{tabular}{llcc}
\hline 1 & 0 & 423.4 & 958.4 \\
2 & 1 & 372.1 & 1502.7 \\
3 & 3 & 364.3 & 1598.0 \\
4 & 5 & 352.6 & 1629.3 \\
\hline
\end{tabular}


pared with no $\mathrm{Al} / \mathrm{B} / \mathrm{Fe}_{2} \mathrm{O}_{3}$ nano thermite, the high-temperature exothermic peak of $\mathrm{AP}$ is shifted to lower temperature by $70.8^{\circ} \mathrm{C}$ when the content of $\mathrm{Al} / \mathrm{B} / \mathrm{Fe}_{2} \mathrm{O}_{3}$ nano thermite is $5 \%$, and the heat released is enhanced by $70 \%$. However, the exothermic peak of thermite reaction can be hardly observed as the content of $\mathrm{Al} / \mathrm{B} / \mathrm{Fe}_{2} \mathrm{O}_{3}$ nano thermite is much lower than that of AP.

\subsection{Effects of $\mathrm{Al} / \mathrm{B} / \mathrm{Fe}_{2} \mathrm{O}_{3}$ nano thermite on the heat of explosion of HTPB propellant}

From Table 5, it can be seen that the heat of explosion of propellants prepared with $\mathrm{Al} / \mathrm{B} / \mathrm{Fe}_{2} \mathrm{O}_{3}$ nano thermite are higher than that with no $\mathrm{Al} / \mathrm{B} / \mathrm{Fe}_{2} \mathrm{O}_{3}$ nano thermite. Two reasons can be responsible for this result, on the one hand, the addition of $\mathrm{Al} / \mathrm{B} / \mathrm{Fe}_{2} \mathrm{O}_{3}$ nano thermite catalyzes the decomposition of AP in propellant, which increased the heat release of AP; on the other hand, the heat release of thermite reaction also makes the heat of explosion higher.

\section{Conclusions}

$\mathrm{Al} / \mathrm{B} / \mathrm{Fe}_{2} \mathrm{O}_{3}$ nano thermite has good compatibility with HTPB and DOS, and it can be used in HTPB propellant. Both tensile strength and elongation of the propellant samples show a tendency of raise at first and reduce later as the increasing $\mathrm{Al} / \mathrm{B} / \mathrm{Fe}_{2} \mathrm{O}_{3}$ nano thermite content. The tensile strength and elongation of propellant prepared with $3 \% \mathrm{Al} / \mathrm{B} / \mathrm{Fe}_{2} \mathrm{O}_{3}$ nano thermite have the increase of $15.3 \%$ and $32.1 \%$ respectively compared with the propellant with

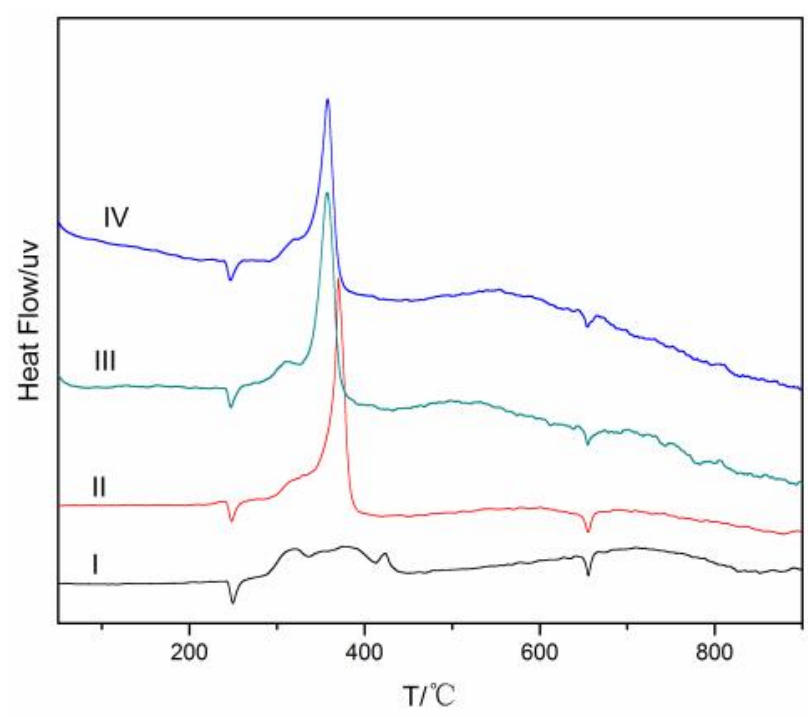

Figure 3. DSC curves of propellants prepared with different content of $\mathrm{Al} / \mathrm{B} / \mathrm{Fe}_{2} \mathrm{O}_{3}$ nano thermite no $\mathrm{Al} / \mathrm{B} / \mathrm{Fe}_{2} \mathrm{O}_{3}$ nano thermite. The decomposition of AP in HTPB propellant can be catalyzed by $\mathrm{Al} / \mathrm{B} / \mathrm{Fe}_{2} \mathrm{O}_{3}$ nano thermite. The hightemperature exothermic peak of $\mathrm{AP}$ is shifted to lower temperature and the heat released is enhanced with the addition of $\mathrm{Al} / \mathrm{B} / \mathrm{Fe}_{2} \mathrm{O}_{3}$ nano thermite. The heat of explosion of HTPB propellant can also be enhanced by the addition of $\mathrm{Al} / \mathrm{B} / \mathrm{Fe}_{2} \mathrm{O}_{3}$ nano thermite.

\section{References}

[1] Plantier, K.B., Pantoya, M.L., Gash, A.E. (2005). Combustion wave speeds of nanocomposite $\mathrm{Al} / \mathrm{Fe}_{2} \mathrm{O}_{3}$ : the effects of $\mathrm{Fe}_{2} \mathrm{O}_{3}$ particle synthesis technique. Combustion and Flame, 140: 299-309.

[2] Pantoya, M.L., Granier, J.J. (2005). Combustion behavior of highly energetic thermites: Nano versus micron composites. Propellant Explosive Pyrotechnic, 30: 53-61.

[3] Perry, W.L., Smith, B.L., Christopher, J. (2004). Nano-scale tungsten oxides for metastable intermolecular composites. Propellant Explosive Pyrotechnic, 14: 99-105.

[4] Blobaum, K.J., Reiss, M.E., Plitzko, J.M., et al. (2003). Deposition and characterization of a self-propagating $\mathrm{CuO}_{\mathrm{x}} / \mathrm{Al}$ thermite reaction in a novel multilayer foil geometry. $A p$ plied Physics, 94: 2915-2922.

[5] Prakash, A, McCormick, A.V., Zachariah, M.R. (2005). Synthesis and reactivity of a super-reactive metastable intermolecular composite formulation of $\mathrm{Al} / \mathrm{KMnO}_{4}$. Advanced Materials, 17: 900-903.

[6] Yen, N.H., Wang, L.Y. (2012). Reactive metals in explosives. Propellant Explosive Pyrotechnic, 37: 143-155.

[7] Pang, W.Q., Fan, X.Z., et al. (2014). Effects of different nano-metric particles on theproperties of composite solid propellants. Propellant Explosive Pyrotechnic, 39: 329336.

Table 5. Heat of explosion of propellant samples

\begin{tabular}{cc}
\hline serial number & $\begin{array}{c}\text { heat of explosion } \\
\text { /MJ·kg-1 }\end{array}$ \\
\hline 1 & 6.10 \\
2 & 6.62 \\
3 & 6.91 \\
4 & 7.45 \\
\hline
\end{tabular}


[8] Chandru, R.A., Patra, S., Oommen, C., et al. (2012). Exceptional activity ofmesoporous b$\mathrm{MnO}_{2}$ in the catalytic thermal sensitization of ammonium perchlorate. Journal of Materials Chemistry, 22: 6536-6538.

[9] Shen, L.H., Li, G.P., et al. (2014). Preparation and characterization of $\mathrm{Al} / \mathrm{B} / \mathrm{Fe}_{2} \mathrm{O}_{3}$ nanothermites. Science China Chemistry, 57: 787-802.

[10] Beach, N.E., Canfield, V.K. (1971). Compatibility of explosives with polymers(III), AD 721004. Spring field: NTIS.

[11] Li, J.Z., Wang, B.Z., Fan, X.Z., et al. (2013). Interaction and Compatibility Between DAAzF and Some Energetic Materials. Defence Technology, 9: 153-156.
[12] Politzer, P., Lane, P. (1998). Energetics of ammonium perchlorate decomposition steps. Journal of Molecular Structure-Theochem, 454: 229-235.

[13] Kohga, M. (2011). Burning characteristics and thermochemical behavior of AP/ HTPB composite propellant using coarse and fine AP particles. Propellant Explosive Pyrotechnic, 36: 57-64.

[14] Gao, K., Li, G.P., Luo, Y.J., et al. (2014). Preparation and characterization of the $\mathrm{AP} / \mathrm{Al} / \mathrm{Fe}_{2} \mathrm{O}_{3}$ ternary nano-thermites. Journal of Thermal Analysis Calorimetry, 118: 43-49. 